\title{
PENGARUH DARI BRAND TRUST, BRAND IMAGE DAN REPUTATION TERHADAP BRAND LOYALTY KOPI LOKAL DI JAKARTA
}

\author{
Varian Jastine \\ Program Studi Magister Manajemen Universitas Tarumanagara \\ varian.117191018@stu.untar.ac.id
}

Masuk : 30-11-2020, revisi : 21-12-2020, diterima untuk diterbitkan : 21-12-2020

\begin{abstract}
The key to the success of a business or company is none other than brand loyalty by customers. So, the increase in brand loyalty needs to be considered. Some factors can affect the increase in brand loyalty. Brand loyalty can be influenced by several factors such as brand trust, brand image, and brand reputation. This study will discuss the effect of brand trust, brand image, and brand reputation on local coffee brand loyalty in Jakarta. Sampling using nonprobability sampling with a purposive method to obtain appropriate characteristics for researchers. Respondents are local coffee consumers who live in Jakarta and are aged under 18-25 years and over as many as 140 respondents. The data analysis technique uses structural equation modeling. The results of this study indicate that brand trust, brand image, and brand reputation have a positive effect on brand loyalty.
\end{abstract}

Keywords: Brand Trust, Brand Image, Brand Reputation, Brand Loyalty

\begin{abstract}
Abstrak: Kunci dari kesuksesan suatu bisnis atau perusahaan tidak lain adalah loyalitas merek oleh pelanggan. Maka, peningkatan terhadap loyalitas merek perlu untuk diperhatikan. Terdapat faktor-faktor yang dapat mempengaruhi peningkatkan loyalitas merek tersebut. Brand loyalty dapat dipengaruhi oleh beberapa faktor seperti brand trust, brand image, dan brand reputation. Penelitian ini akan membahas pengaruh dari brand trust, brand image dan brand reputation terhadap brand loyalty kopi lokal di Jakarta. Pengambilan sampel menggunakan non-probability sampling dengan metode purposive untuk mendapatkan karakterisik yang sesuai bagi peneliti. Responden merupakan konsumen kopi lokal yang berdomisili di Jakarta dan berusia dibawah 18 - 25 tahun ke atas sebanyak 140 responden. Teknik analisa data menggunakan pemodelan persamaan struktural. Hasil dari penelitian ini memperlihatkan bahwa brand trust, brand image dan brand reputation berpengaruh secara positif terhadap brand loyalty.
\end{abstract}

Kata Kunci: Brand Trust, Brand Image, Brand Reputation, Brand Loyalty

\section{PENDAHULUAN}

Kopi merupakan minuman dari hasil seduhan biji kopi yang telah diproses menjadi bubuk kopi. Kopi sudah menjadi kebutuhan pokok dan kebutuhan sosial di Indonesia bahkan ada beberapa tipe peminum kopi dimulai dari peminum yang baru mencoba hingga pencinta kopi. Peningkatkan produksi kopi yang meningkat setiap tahun menjadi pertimbangan penting bagi para pengusaha muda yang berlomba-lomba memulai bisnis kopi. Tingginya persaingan usaha membuat konsumen harus memilih brand / merek yang akan mereka pilih dan setia kepada brand tersebut. Penting bagi pengusaha kopi lokal Indonesia yang berbisnis kopi untuk membuat strategi pemasaran yang dapat meningkatkan brand loyalty usaha kopi mereka. Brand loyalty menjadi sebuah pertimbangan penting bagi pengusaha kopi lokal Indonesia untuk kesetiaan konsumen dalam memilih produk kopi lokal. Setiap konsumen memiliki tujuan yang berbeda dalam mengkonsumsi kopi. Ada konsumen yang mengkonsumsi kopi untuk lifestyle dan konsumen yang mengkonsumsi kopi karena kebutuhan, contoh: konsumen akan terasa lebih nyaman, tenang dan fokus apabila mengkonsumsi kopi pada saat beraktivitas. Usaha kopi lokal terus berkembang dan penting untuk memahami faktor yang mempengaruhi 
brand loyalty pada usaha kopi lokal. Terdapat beberapa variabel yang dapat menjelaskan brand loyalty. Menurut Putra dan Keni (2020), brand loyalty secara langsung dipengaruhi oleh brand trust dan perceived value dan brand experience terhadap brand loyalty memiliki pengaruh apabila dijelaskan melalui brand love. Dalam penelitian Chinomona (2016), brand trust mempengaruhi brand loyalty selain itu penelitian yang dilakukan oleh Upamannyu, Gulati, dan Mathur (2014) ditemukan bahwa brand trust, brand affect, dan brand image memberikan pengaruh pada brand loyalty.

\section{Tujuan Penelitian}

Tujuan dari penelitian ini, pertama untuk mengetahui pengaruh dari brand trust terhadap brand loyalty, selanjutnya untuk mengetahui pengaruh dari brand image terhadap brand loyalty dan terakhir untuk mengetahui pengaruh dari brand reputation terhadap brand loyalty.

\section{TINJAUAN PUSTAKA}

Brand trust merupakan salah satu faktor yang mempengaruhi brand loyalty. Menurut Chaudhuri dan Holbrook (2001), brand trust merupakan keinginan/kemauan konsumen untuk percaya kepada sebuah merek. Pengusaha berusaha untuk membangun brand yang mampu meningkatkan rasa percaya konsumen dengan tujuan meningkatkan penjualan dan penghasilan. Menurut Chinomona (2016), brand trust yang positif dapat menghasilkan rasa percaya pelanggan akan segala janji yang akan diperoleh dari suatu produk atau jasa yang sesuai dengan harapan pelanggan.

Faktor lain yang mempengaruhi brand loyalty adalah brand image. Menurut Upamannyu, Gulati, dan Mathur (2014), brand image merupakan pandangan seorang konsumen terhadap suatu brand. Brand image memiliki pengaruh terhadap brand loyalty (Vázquez-Carrasco \& Foxall, 2006). Abd Aziz, Jusoh, dan Amlus (2018) juga memiliki pendapat yang sama bahwa brand image mempengaruhi brand loyalty.

Faktor terakhir yang mempengaruhi brand loyalty adalah brand reputation. Menurut Dowling dan Moran (2012), Abratt dan Kleyn (2012), brand reputation merupakan suatu proses membangun dan mempertahankan reputasi positif perusahaan. Menurut Loureiro, Sarmento, dan Le Bellego (2017), brand reputation memiliki pengaruh terhadap brand loyalty. Selanjutnya menurut Roper dan Fill (2012), bahwa brand reputation memiliki pengaruh terhadap brand loyalty. penelitian:

Berdasarkan uraian pengertian dan keterkaitan antar variabel, maka berikut adalah model

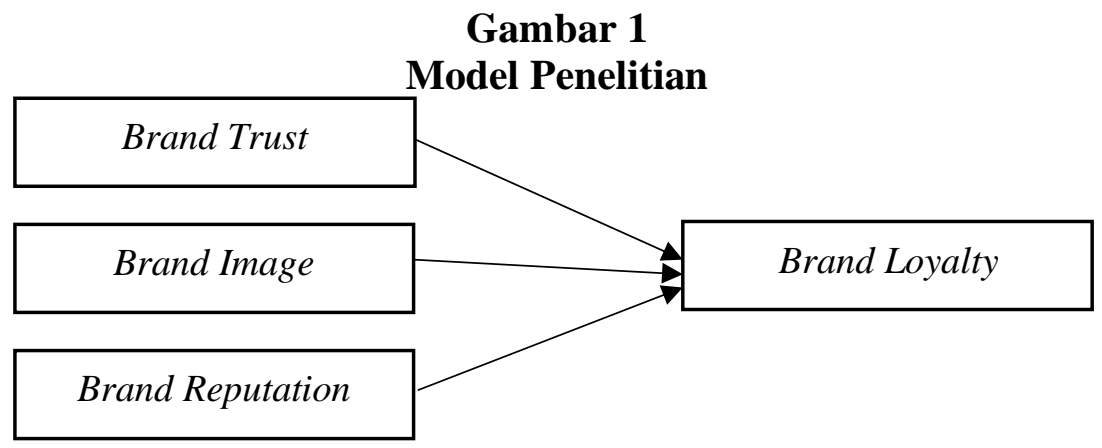

Berdasarkan hasil teori dan kerangka pemikirian di atas, maka rumusan hipotesis penelitian adalah sebagai berikut:

$\mathrm{H}_{1}$ : Brand trust memiliki pengaruh positif terhadap brand loyalty kopi lokal di Jakarta.

$\mathrm{H}_{2}$ : Brand image memiliki pengaruh positif terhadap brand loyalty kopi lokal di Jakarta.

$\mathrm{H}_{3}$ : Brand reputation memiliki pengaruh positif terhadap brand loyalty kopi lokal di Jakarta.

\section{METODOLOGI PENELITIAN}

Dalam penelitian ini, jenis penelitian yang digunakan adalah penelitian deskriptif dengan pendekatan cross sectional. Sampel yang dilibatkan adalah orang yang telah mengetahui 
mengkonsumsi kopi dan berdomisili di Jakarta. Metode pengampilan sampel menggunakan metode non-probability sampling dengan teknik convenience sampling. Penyebaran data menggunakan kuesioner melalui Google Form. Sampel yang digunakan dalam penelitian ini adalah sebanyak 140 orang, mayoritas responden berumur 22-25 tahun (47,9\%), berdomisili di Jakarta Barat $(51,4 \%)$ dan berpenghasilan < Rp 8.000.000 (58,3\%), frekuensi pembelian sebanyak 1 kali dalam 1 bulan $(38,6 \%)$. Indikator penelitian yang digunakan dalam penelitian ini dapat dilihat pada tabel berikut ini.

\section{Tabel 1}

Indikator Pengukuran Variabel

\begin{tabular}{|c|c|c|}
\hline Variabel & Item & Sumber \\
\hline Brand Trust & 5 item & Delgado-Ballester (2004); Chaudhuri \& Holbrook (2001) \\
\hline Brand Image & 5 item & $\begin{array}{c}\text { Sasmita \& Suki (2015); Jalilvand \& Samiei (2012); } \\
\text { Abd Aziz, Jusoh, \& Amlus (2018) }\end{array}$ \\
\hline Brand Reputation & 2 item & Rani \& Suradi (2017) \\
\hline Brand Loyalty & 5 item & $\begin{array}{c}\text { Yoo, Donthu, \& Lee (2000); Beatty, Kahle, \& Homer (1988); } \\
\text { Chaudhuri \& Holbrook (2001); Ene \& Özkaya (2014) }\end{array}$ \\
\hline
\end{tabular}

\section{HASIL DAN KESIMPULAN}

Hasil analisis convergent validity (nilai AVE > 0,50 dan loading factor $>0,70$ ) lalu discriminant validty (kriteria dari Fornell-Lacker dan nilai cross loading) serta nilai dari composite reliability dan Cronbach alpha menunjukkan nilai $>0,6$. Hal ini menunjukkan bahwa semua indikator dalam penelitian ini sudah memenuhi nilai syarat minimum dari metode pengukuran yang digunakan. Hasil uji $\mathrm{R}^{2}$ menunjukkan bahwa brand trust, brand image, dan brand reputation secara memberikan pengaruh yang kuat terhadap brand loyalty dengan nilai 0,677 . Hasil uji $Q^{2}$ pada penelitian ini menunjukkan nilai $Q^{2}$ yang dihasilkan adalah sebesar 0,406 (lebih besar dari 0) yang berarti bahwa konstruk variabel yang terdapat dalam penelitian ini relevan untuk mengukur model penelitian yang telah terbentuk sebelumnya dengan baik. Selanjutnya nilai GoF tergolong besar karena nilainya sebesar 0,681. Nilai dari uji path coefficient menunjukkan bahwa variabel brand trust, brand image dan brand reputation memiliki pengaruh positif terhadap brand loyalty. Selanjutnya adalah uji effect size atau uji $\mathrm{f}^{2}$, menunjukkan bahwa brand image memiliki tingkat prediktor sebesar 0,165 . Selanjutnya adalah uji hipotesis dengan melakukan uji t, sebagai berikut:

\section{Tabel 2}

Uji t dan Uji Signifikansi

\begin{tabular}{|c|c|c|c|c|}
\hline Keterangan & Path Coefficient & t-statistics & p-value & Keterangan \\
\hline Brand Image -> Brand Loyalty & 0,418 & 4,086 & 0,000 & Tidak Ditolak \\
\hline Brand Reputation -> Brand Loyalty & 0,232 & 2,848 & 0,004 & Tidak Ditolak \\
\hline Brand Trust -> Brand Loyalty & 0,264 & 3,673 & 0,000 & Tidak Ditolak \\
\hline
\end{tabular}

Berdasarkan Tabel 2 diketahui bahwa $\mathrm{H}_{1}$ tidak ditolak karena variabel brand trust terbukti mampu memberikan pengaruh secara positif pada brand loyalty. Hal ini dibuktikan dengan nilai $t$ statistics sebesar 3,673 yang lebih besar dari cut off value sebesar 1,96 dan $p$ values nya yaitu 0 lebih kecil dari cut off value yang ditetapkan yaitu sebesar 0,05 . Selanjutnya $\mathrm{H}_{2}$ tidak ditolak karena variabel brand image terbukti mampu memberikan pengaruh secara positif pada brand loyalty. Hal ini dibuktikan dengan nilai $t$ statistics sebesar 4,086 yang lebih besar dari cut off value sebesar 1,96 dan p-values nya yaitu 0,004 lebih kecil dari cut off value yang ditetapkan yaitu sebesar 0,05 . Terakhir, $\mathrm{H}_{3}$ tidak dtolak karena variabel brand reputation terbukti mampu memberikan pengaruh secara positif pada brand loyalty kopi lokal di Jakarta. Hal ini dibuktikan dengan nilai $t$ statistics sebesar 2,848 yang lebih besar dari cut off value sebesar 1,96 dan p-values nya yaitu 0 yang lebih kecil dari cut off value yang ditetapkan yaitu sebesar 0,05 . 


\section{KESIMPULAN DAN SARAN}

Hasil penelitian menunjukan bahwa seluruh hipotesis tidak ditolak, dengan demikian, hasil penelitian juga memberikan saran agar pengusaha dapat menjaga rasa percaya, citra merek dan reputasi merek karena hal tersebut memiliki pengaruh yang signifikan terhadap loyalitas merek dari konsumen. Penelitian ini secara teoritis dapat memberikan kontribusi terhadap penelitian terhadap perilaku konsumen dan pemasaran, secara khusus terhadap brand trust, brand image, brand reputation, dan brand loyalty. Bagi penelitian selanjutnya, dihimbau untuk menggunakan variabel lain yang dapat mempengaruhi brand loyalty guna untuk memperluas cakupan penelitian. Diharapkan pada penelitian selanjutnya dapat dikembangkan dalam konteks produk atau mungkin jasa pada industri yang berbeda.

\section{DAFTAR PUSTAKA}

Abd Aziz, S., Jusoh, M. S., \& Amlus, M. H. (2018). The moderating role of technology anxiety on brand service quality, brand image and their relation to brand loyalty. International Journal of Internet Marketing and Advertising, 12(3), 270-289. https://doi.org/10.1504/IJIMA.2018.093410

Abratt, R., \& Kleyn, N. (2012). Corporate identity, corporate branding and corporate reputations: Reconciliation and integration. European Journal of Marketing, 46(7), 10481063. https://doi.org/10.1108/03090561211230197

Beatty, S. E., Kahle, L. R., \& Homer, P. (1988). The involvement-commitment: Theory and implications. Journal of Business Research, 16(2), 149-167.

Chaudhuri, A., \& Holbrook, M. B. (2001). The chain of effects from brand trust and brand affect to brand performance: The role of brand loyalty. Journal of Marketing, 65(2), 8193. https://doi.org/10.1509/jmkg.65.2.81.18255

Chinomona, R. (2016). Brand communication, brand image and brand trust as antecedents of brand loyalty in Gauteng Province of South Africa. African Journal of Economic and Management Studies, 7(1), 124-139. https://doi.org/10.1108/AJEMS-03-2013-0031

Delgado-Ballester, E. (2004). Applicability of a brand trust scale across product categories. European Journal of Marketing, 38(5/6), 573-592. https://doi.org/10.1108/03090560410529222

Dowling, G., \& Moran, P. (2012). Corporate reputations: Built in or bolted on? California Management Review, 54(2), 25-42. https://doi.org/10.1525/cmr.2012.54.2.25

Ene, S., \& Özkaya, B. (2014). A study on corporate image, customer satisfaction and brand loyalty in the context of retail stores. Asian Social Science, 10(14), 52-66. https://doi.org/10.5539/ass.v10n14p52

Jalilvand, M. R., \& Samiei, N. (2012). The effect of electronic word of mouth on brand image and purchase intention An empirical study in the automobile industry in Iran. Marketing Intelligence \& Planning, 30(4), 460-476. https://doi.org/10.1108/02634501211231946

Loureiro, S. M. C., Sarmento, E. M., \& Le Bellego, G. (2017). The effect of corporate brand reputation on brand attachment and brand loyalty: Automobile sector. Cogent Business and Management, 4(1). https://doi.org/10.1080/23311975.2017.1360031

Putra, T. W., \& Keni, K. (2020). Brand experience, perceived value, brand trust untuk memprediksi brand loyalty: Brand love sebagai variabel mediasi. Jurnal Muara Ilmu Ekonomi Dan Bisnis, 4(1), 184-193. https://doi.org/10.24912/jmieb.v4i1.7759

Rani, N. S. A., \& Suradi, Z. (2017). International brand vs. local brand: An evaluation of brand trust, brand reputation, customer satisfaction and purchase intention of Malaysian customers. Journal of Business and Retail Management Research, 11(3), 179-185.

Roper, S., \& Fill, C. (2012). Corporate reputation brand and communication. Financial Times/Prentice Hall. 
Sasmita, J., \& Mohd Suki, N. (2015). Young consumers' insights on brand equity: Effects of brand association, brand loyalty, brand awareness, and brand image. International Journal of Retail and Distribution Management, 43(3), 276-292. https://doi.org/10.1108/IJRDM02-2014-0024

Upamannyu, N. K., Gulati, C., \& Mathur, G. (2014). Effect of brand trust, brand image on customer brand loyalty in FMCG sector at Gwalior Region. Scholars World-IRMJCR, 2(2), 83-93.

Vázquez-Carrasco, R., \& Foxall, G. R. (2006). Influence of personality traits on satisfaction, perception of relational benefits, and loyalty in a personal service context. Journal of Retailing and Consumer Services, 13(3), 205-219. https://doi.org/10.1016/j.jretconser.2005.08.006

Yoo, B., Donthu, N., \& Lee, S. (2000). An examination of selected marketing mix elements and brand equity. Journal of the Academy of Marketing Science, 28(2), 195-211. https://doi.org/10.1177/0092070300282002 